\title{
Konsep Kecerdasan Emosional dalam Perspektif Pendidikan Islam
}

\author{
Anisatul Masruroh \\ anisatul.masruroh@gmail.com \\ MI Nafiatul Huda Demaan
}

\begin{abstract}
Abstrak
Kecerdasan emosi adalah sebuah istilah umum, akan tetapi jika dikaji lebih dalam dan dipelajari isinya sebenarnya bukanlah hal baru. Dalam pengajaran Islam sendiri sudah termaktub dalam pendidikan seperti kesadaran diri (QS. Az Zumara: 15), pengendalian diri (QS. Al Hadid: 23), ketekunan, antusiame, motivasi diri (QS. Thaaha: 67-68 ), empati kepada sesama (QS. An Nur: 2), dan kemampuan sosial (QS. Al Hujurat: 13). Inti yang ingin didapatkan adalah bagaimana seseorang itu mengetahui, menguasai, dan mengontrol emosi yang biasanya merujuk kepada perilaku kedewasaan seseorang yang biasanya disebut kecerdasan emosi. Kaitan konsep kecerdasan emosi dan konsep pendidikan islam telah terlihat pada level kaitan kontrol diri dan relasi sosial antar manusia. Akan tetapi tidak bisa dipunkiri bahwa konsep kecerdasan emosi memiliki beberapa kekurangan dalam kaitannya dengan perkembangan dan peningkatan nilai penghambaan kepada Allah
\end{abstract}

Emotional intelligence is indeed a relative term but when examined more deeply and study the actual contents are not considered new. In the Islamic teaching itself are included in the development of Islamic education such as self-awareness (QS. Az Zumara: 15), self-control (QS. Al Hadid: 23), perseverance, enthusiasm, motivation to self (QS. Thaaha: 67-68), empathy toward others (QS. An Nur: 2), and social skills (QS. Al Hujurat: 13). The procession in essence is resulted to how a person will know, master and control emotions all of which are often referred to maturity attitude of person namely emotional intelligence. The linkage concept of emotional intelligence to the concept of Islamic education has 
been seen at the level of the relationship of self (self-control) and social relations between human (horizontal). But it cannot deny that the concept of emotional intelligence has some shortcomings on several matters relating to the development and increase the value of devotion to God Almighty.

Kata kunci: kecerdasan emosi, perspektif, pendidikan Islam

\section{Pendahuluan}

Pemahaman manusia terhadap kecerdasan memiliki muatan yang sangat sempit, serangkaian penting kemamuan yang sangat besar pengaruhnya dalam menentukan keberhasilan di dalam kehidupan.

Dengan memanfaatkan penelitian yang menggemparkan yang mendefinisikan ulang apa arti cerdas dalam kaitannya dengan otak dan perilaku, seorang tokoh psikologi kenamaan Goleman telah memperlihatkan faktor-faktor yang terkait mengapa orang yang ber-IQ tinggi gagal dan orang yang ber-IQ sedang-sedang saja menjadi sukses. Faktor-faktor ini mengacu pada suatu cara lain untuk menjadi cerdas. Goleman bahkan berani mengatakan bahwa IQ menyumbangkan kirakira $20 \%$ bagi faktor-faktor yang menentukan sukses dalam hidup, maka 80\% diisi oleh kekuatan-kekuatan lain (Daniel Goleman, 2003:44).

Cara yang disebutnya "Kecerdasan Emosional" diyakini memiliki peran pentig dalam kehidupan dan sangat berpengaruh terhadap perkembangan emosi terhadap penyesuaian pribadi dan sosial. Beberapa hasil penelitian membuktikan bahwa setiap emosi mempengaruhi cara penyesuaian pribadi dan sosial seseorang dan dapat bersifat fisik atau psikologis atau bahkan keduanya dan emosi manusia berkembang 
melalui mekanisme hidup. Berawal dari perkembangan emosi melalui mekanisme kelangsungan hidup beberapa guru dan orang tua mencoba untuk mengadakan penilaian. Disimpulkan bahwa keadaan rata-rata anak-anak pada soal ini semakin memburuk dengan mantap. Tak ada masalah yang menonjol, semua indikator merayap dengan mantap ke arah yang keliru (Goleman, 2003:329).

Perlu disadari dengan pandangan psikologis, bimbingan dan pengarahan yang bernilai pedagogis tidak akan menemukan sasaran yang tepat, yang berkibat pada pencapaian produk pendidikan yang tepat pula. Antara pedagogik (ilmu pendidikan) saling mengembangkan dan memperkokoh proses pengembangan akademiknya lebih lanjut, juga dalam proses pencapaian tujuan pembudayaan manusia melalui proses kependidikan. Berbagai hambatan dan rintangan yang bersifat psikologi (muslim) untuk diperhatikan konseptor pendidikan (guru dan pendidik formal lainnya) agar hambatan dan rintangan psikologi itu dapat diatasi dengan metode pendidikan yang tepat guna atau berdaya guna (Arifin, 1993:136).

Peter Solovey dalam Goleman (2003:513) menyatakan bahwa salah satu aspek kecerdasan emosional, yaitu kecerdasan "sosial" sebagai kemampuan untuk memahami orang lain, bertindak bijaksana dalam hubungan antar manusia. Ia juga menganut pandangan yang lebih luas dan berusaha menanamkan kembali dalam kerangka fikir, apa yang dibutuhkan manusia untuk meraih sukses dalam kehidupannya. Sementara itu tugas pendidikan Islam tidak hanya berhenti pada sekedar menumbuhkembangkan potensi peserta didik, lebih dari itu pendidikan 
Islam mengemban misi mengarahkan, membentuk, dan mendidik peserta didik sesuai dengan tujuan hidup manusia menurut ajaran Islam, sehingga terbentuknya kepribadian yang dilengkapi dengan sejumlah kompetensi sesuai nilai-nilai yang diajarkan dalam Islam guna menunjang pencapaian "sukses menjadi penanggung jawab bumi sebagai khalifah Allah" inilah yang kemudian di sebut dengan insan kamil (Asifudin, 2009: 18-19).

Pendidikan Islam merupakan bagian bagian dari sistem kehidupan umat Islam dari sistem kehidupan umat Islam dan mempunyai tujuan yang menjadi bagian dari tujuan hidup manusia menurut Islam (Langgulung, 1995: 5). Misi ini merupakan bagian dari tujuan dari kecerdasan emosional, kolerasi keduanya akan menggasilkan pribadi yang sempurna, ejawantah dari keberhasilan peserta didik dalam mengelola segenap perasaan emosional yang dimilikinya, sehingga menjadi pribadi yang sesuai dengan karakter Islam, balance dalam mengelola kepentingan dunia dan ukhrowi melalui kepekaan sosial yang terbangun dalam kepercayaan yang tumbuh dalam dirinya.

Munculnya konsep kecerdasan emosional (Emotional Intelegence) semakin banyak dikaji dan dipelajari sebagai suatu kajian yang terlepas dari kesamaan dan terhindarnya tumpang tindih kajian yang telah ada, maka penulis berusaha untuk memfokuskan kajian kecerdasan emosional dipandang dari kacamata pendidikan Islam. Karena konsep pendidikan Islam diharapkan dapat berperan membangun manusia yang tentunya nanti dapat diharapkan menjadi manusia-manusia seutuhnya (kaffah). Mengingat dari konsep kecerdasan emosional dari barat di atas 
lebih cenderung menekankan pada diri dan sosialnya saja. Belum terlihat adanya keterkaitan antara konsep kecerdasan emosional tersebut dengan ajaran Tuhannya. Maka, perlu bagi penulis untuk meninjau ulang konsepkonsep kecerdasan emosional tersebut dalamsudut pandang pendidikan Islam. Sehingga nantinya konsep kecerdasan emosional yang telah banyak dikaji dapat dipergunakan dalam membantu masalah-masalah kependidikannya dan keberhasilannya, khususnya dalam pendidikan Islam.

Terlepas dari ada tidaknya kajian konsep kecerdasan emosional dalam perspektif Islam, terangkatnya konsep kecerdasan emosional ini kepermukaan berkat buku best seller karyha Daniel Goleman yang sangat laris pada tahun 1995, Emotional Intellegence. Menariknya konsep kecerdasan emosional memang bukan dimulai dari kecenderungan animo masyarakat terhadap konsep kecerdasan emosional, akan tetapi dimulai dari peran EI dalam membesarkan dan mendidik anak-anak, selanjutnya orang menyadari pentingnya konsep ini baik dilapangan kerja maupun hampir di semua tempat lain yang mengharuskan manusia saling berhubungan. penelitian-penelitian telah menunjukkan bahwa keterampilan EI yang sama membuat siswa yang lebih bersemangat tinggi dalam belajar, atau untuk disukai teman-temannya diarena bermain, juga akan membantunya dua puluh tahun kemudian ketika sudah masuk kedunia kerja atau ketika sudah berkeluarga. Dengan demikian, pembentukan perilaku itu tidak dimulai dari pembinaan keutuhan jasmani, justru pembentukan perilaku itu dimulai dari 
ketrampilan-ketrampilan mental, intelektual dan emosional (Wijaya, 1992:161).

Berkaitan dengan hal tersebut, kecerdasan emosional akan tumbuh berkembang dengan baik manakala ia memperoleh pendidikan yang menyeluruh komprehensif, oleh karenanya Pendidikan Islam tentunya juga harus mempunyai andil dalam mengatasi permasalahan pendidikan yang tentunya mengenai hubungan dengan konsep kecerdasan emosional mengingat dari bagian-bagian yang digagas Islam sendiri telah ada beberapa pembahasan tentang emosi, tetapi dapat dipahami penekanan kajian tentang konsep kecerdasan emosional ini kurang begitu digagas oleh psikolog Islam dalam kaitannya dengan pendidikan Islam. Harapan yang muncul tentunya bagaimana pendidikan Islam juga berhasil dalam permasalahan kehidupan yang khususnya menyangkut masalah kecerdasan emosional.

\section{Metode Penelitian}

Jenis penelitian ini adalah penelitian kualitatif yang menitik beratkan pada penelitian kepustakaan (library research) dengan mengkaji teks al-Qur'an, hadis, buku-buku, dan naskah yang bersumber dari khazanah kepustakaan yang relevan dengan permasalahan yang diangkat dalam penelitian ini (Efendy, 1989: 192). Sumber data yang digunakan terbagi menjadi dua bentuk primer dan sekunder. Data primer adalah buku yang dijadikan pegangan utama berupa tafsir dan hadis. Sedangkan data sekunder adalah buku buku masih dianggap relevan dengan kajian penelitian (Arikunto, 1993 :131). Metode analisis yang digunakan adalah 
analisis diskriptif, yang kemudian menentukan hubungan antar kategori dengan yang lain, dilakukan metode analisis dan serta interpretasi sesuai dengan peta penelitian yang dibimbing oleh masalah dan tujuan penelitian. Proses analisis data ini dilakukan untuk mewujudkan kontruksi teoritis sesuai dengan masalah penelitian (Surakhmand, 1980: 93).

\section{Pembahasan}

\section{Konsep Kecerdasan Emosional}

Kata emosi bisa secara sederhana didefinisikan sebagai menerapkan "gerakan" baik secara metafora maupun harfiah, untuk mengeluarkan perasaan. Emosi sejak lama dianggap memiliki kedalaman dan kekuatan sehingga dalam bahasa latin, emosi dijelaskan sebagai motus anima yang arti harfiahnya "jiwa yang menggerakkan kita". Emosi bukanlah sesuatu yang bersifat positif atau negatif tetapi emosi berlaku sebagai sumebr energi, autentisitas, semangat manusia yang paling kuat dan dapat memberikan kita sumber kebijakan intuitif (Cooper, Sawaf, 2002: xiv). Emosi menurut Goleman (2003: 411) adalah setiap kegiatan atau pergolakan pikiran, perasaan, nafsu, setiap keadaan mental yang hebat dan meluap-luap.

Pengertian lain dari emosi merupakan luapan perasaan yang berkembang dan surut dalam waktu singkat dan reaksi psikologis dan fisiologis seperti; kegembiraan, kesedihan, kecintaan, keberanian yang subjektif (Tim Redaksi, 1991:261). Berangkat dari pemikiran emosi di atas, menurut Daniel Goleman kecerdasan emosional adalah kemampuan untuk memotivasi diri sendiri dan bertahan menghadapi frustasi; 
mengendalikan dorongan hati dan tidak melebih-lebihkan kesenangan; mengatur suasana hati dan menjaga agar beban stress tidak melumpuhkan kemampuan berfikir; berempati dan berdoa (Daniel Goleman, 2003:45).

Kecerdasan Emosional menurut Goleman (1999: 580) dalam The Development of a Concept and Test of Psychologikal well-being, sebagai "serangkaian kemampuan pribadi, emosi dan sosial yang mempengaruhi kemampuan seseorang untuk berhasil dalam mengatasi tuntutan dan tekanan lingkungan". Dan selama beberapa tahun belakangan beberapa pakar telah mengajukan teori masing-masing dengan gagasan yang kurang lebih sama. Cooper, Ayman (2002: xv) menerjemahkan kecerdasan Emosional adalah kemampuan merasakan, memahami, dan secara efektif menerapkan daya dan kepekaan emosi sebagai sumber energi, informasi, koneksi, dan pengaruh yang manusiawi. Sedangkan Ginanjar (2004: vi) mendefiniskan kecerdasan emosional sebagai kecerdasan yang bisa memotivasi kondisi psikologis menjadi pribadipribadi yang matang, yang berbentuk kemampuan merasakan, memahami, dan secara efektif menerapkan daya dan kepekaan emosi sebagai sumber energi, informasi, koneksi dan pengaruh manusia, yang berpusat pada rekonstruksi hubungan yang bersifat sosial. Dengan demikian istilah kecerdasan emosional adalah kemampuan untuk mengenal, menguasai, dan mengendalikan emosi yang ada di dalam diri manusia. (kecerdasan emosional).

Goleman (2003:514) menempatkan kecerdasan emosional dalam lima wilayah, yakni: 1) kesadaran diri, sebagai tolok ukur yang realistis atau kemampuan diri dan kepercayaan diri, 2) pengendalian diri, bertugas 
menangani emosi sehingga berdampak positif pada pelaksanaan tugas, 3) motivasi, sebagai hasrat untuk menggerakkan pada sasaran sekaligus menginisiasi inisiatif untuk bertahan menghadapi kegagalan dan frustasi, 4) empati bertugas untuk merasakan yang dirasakan orang lain, 5) ketrampilan social, untuk menangani emosi dengan baik ketika berhubungan dengan orang lain dan cermat dalam membaca situasi dengan jaringan social sehingga mampu untuk bekerjasama dalam sebuah tim.

Cooper, Sawaf (2002: xli) merumuskan kecerdasan emosional dengan; 1) kecerdasan emosi (emotional literary), untuk membangun kepiawaian dan rasa percaya diri melalui kejujuran emosi, energi emosi, umpan balik emosi, intuisi, rasa tanggung jawab dan koneksi. 2) kebugaran emosi (emotional fitness), untuk mempertegas kesejatian, sifat dapat dipercaya, keuletan, kemampuan untuk mendengarkan, mengelola konflik, dan mengatasi kekecewaan dengan cara yang konstruktif. 3) kedalaman emosi (Emotional depth), untuk mengeksplorasi hidup dan kerja dengan melalui potensi dan bakat ketulusan, kesetiaan pada janji, rasa tanggung jawab, 4) Alkemi emosi (emotional alchemy), untuk memperdalam naluri dan kemampuan kreatif untuk mengatasi masalahmasalah dan tekanan-tekanan yang ada dalam diri manusia.

Sten dan Howard dalam Ginanjar (2003:51), mengindikasikan kecerdasan emosional dengan; jujur kepada semua orang, menerapkan disiplin, bergaul baik dengan orang lain, memiliki suami istri yang mendukung, bekerja lebih giat daripada kebanyakan orang. Sedangkan Revven dalam Sten dan Howard (2004: 39-41) merangkum kecerdasan 
emosional dengan membagi EQ dalam lima area: 1) ranah intra pribadi, terkait dengan kemampuan mengenal dan mengendalikan diri sendiri. 2) ranah antar pribadi, berkaitan dengan keterampilan bergaul dan berinteraksi dengan orang lain. 3) ranah penyesuaian iri, berkaitan dengan kemampuan untuk bersikap lentur dan realistis dalam memecahkan masalah yang muncul. 4) ranah pengendalian stress, sebagai kemampuan untuk tahan menghadapi stress dan mengendalikan impuls. 5) ranah suasana hati optimism, yaitu kemampuan untuk mempertahankan sikap positif yang realistis, terutama dalam menghadapi masa-masa sulit.

Sumbangsih pengembangan pemikiran tentang konsep ciri-ciri kecerdasan emosional tetap akan terus berlanjut sesuai dengan hasil pergesekan ide-ide yang berkaitan dengankonsep tersebut. Meskipun tidak menutup kemungkinan akan muncul konsep-konsep baru tentang ciri-ciri kecerdasan emosional, akan tetapi penulis batasi dari hasil pemikiran Goleman yang nantinya akan dicoba dikaitkan dengan konsep Islam sendiri.

\section{Peran Emotional Intelegence (EI) Terhadap Emotional Quesion (EQ)}

Kecerdasan Intelektual (IQ) sebagai ukuran kemampuan intelektual, analisis, logika, dan rasio seseorang, yang tergambarkan melalui kecerdasan otak untuk menerima, menyimpan, dan mengolah informasi menjadi fakta. Sedangkan kecerdasan emosional (EQ) adalah kemampuan mengenali perasaan sendiri dan perasaan orang lain, 
kemampuan memotivasi diri sendiri, serta kemampuan mengolah emosi dengan baik pada diri sendiri dan orang lain. Keduanya saling berkaitan dalam diri manusia agar hidupnya semakin bermakna, sehingga mampu mengambil keputusan secara tepat sekaligus memberikan sinyal untuk memahami perasaan diri sendiri dan perasaan orang lain.

Kecerdasan emosi dan atau emotional intelegence merujuk kepada kemampuan mengenali perasaan sendiri dan perasaan orang lain, kemampuan memotivasi diri sendiri, dan kemampuan mengelola emosi dengan baik pada diri sendiri dan dalam hubungan dengan orang lain (Goleman, 2003:512). Sedangkan emotional quesion mencakup kemampuan-kemampuan yang berbeda tetapi saling melengkapi, dengan kecerdasan akademik (academik intelligent), yaitu kemampuankemampuan koginitf murni yang diukur dengan IQ, yang membantu untuk memahami dan menghadapi diri sendiri yang kemudian berafiliasi kepada orang lain, tanpa kemampuan tersebut seseorang tidak mungkin dapat menciptakan hubungan baik dengan orang lain (Segal, 2003:24).

Graham (2003:27, 71), menyatakan bahwa kecerdasan emosi seseorang dipengaruhi oleh kehidupan awal individu, yang memiliki keterkaitan fisik, baik dalam bentuk tanggapan-tanggapan sinaptis, atau dalam manifestasi fisik lainnya, termasuk dengan otak manusia. Dengan demikian IQ tanpa EQ dapat menyebabkan seseorang terkotak dalam satu tempat saja, kemampuan untuk beradaptasi dengan lingkungan menjadi terbatas karena kungkungan IQ tanpa diimbangi EQ sehingga hanya mampu menciptakan kecerdasan saja tetapi tidak terimbangi pembentukan moral atau karakter yang sesuai, hal ini di sebabkan 
wilayah EQ meliputi hubungan pribadi dan antar pribadi. EQ bertanggung jawab atas harga diri, kesaadaran diri, kepekaan sosial dan kemampuan adapatasi sosial (Segal, 2003: 26).

Goleman (2003: 61) menyatakan bahwa, EI tidak begitu dipengaruhi oleh faktor keturunan, sehingga membuka kesempatan bagi orang tua dan para pendidik untuk melanjutkan apa yang sudah disediakan oleh alam agar anak mempunyai peluang lebih besar untuk meraih keberhasilan, sedangkan EQ melahirkan sifat-sifat yang membuat diri seseorang menjadi lebih manusiawi (Daniel Goleman, 2003:61). Dengan demikian kemampuan intelektual yang cukup dan dilengkapi dengan karakter, temperamen dan sikap yang matang akan membentuk kehidupan profesional dan personal yang menyenangkan. EI menambahkan kedalaman dan keyakinan sifat manusiawi terhadap kehidupan, berperilaku dengan perasaan. Robert, Ayyan (2002: xviii) dimensi-dimensi kecerdasan manusia yang berperan dalam keberhasilan pribadi dan antarpribadi, keberhasilan organisasi, dan bermanfaat bagi kemanuisaan. Oleh sebab itu EQ dan IQ sangat berpengaruh dalam menciptakan keberhasilan dari suatu pendidikan.

\section{Pendidikan Islam dan Kecerdasan Emosional}

Manusia yang memiliki kepribadian muslim adalah manusia ideal yang mana berarti manusia yang tunduk dan patuh pada aturan Allah. Sehingga proses pendidikan pada akhirnya akan lebih mendekatkan anak didik pada Allah, yang tujuan pokok dari pendidikan Islam adalah mendidik budi pekerti dan pendidikan jiwa (Al Abrasyi, 1993:1). Hal 
tersebut terumuskan dengan: 1) pendidikan ialah tindakan yang dilakukan secara sadar dengan tujuan memelihara dan mengembangkan fitrah seta potensi (sumber daya) insani menuju terbentuknya manusia seutuhnya (insan kamil). 2) pendidikan adalah proses kegiatan secara bertahap dan berkesinambungan seirama dengan perkembangan subjek didik (Marimba, 1962:43).

Pendidikan Islam dimaknai dengan tarbiyah, ta'lim, dan ta'dib mengemban misi yang sama, yang tidak hanya terfokus mengasuh, mendidik dan memelihara pada kemampuan intelektual saja tapi juga harus berimbas terhadap pembentukan akhlak. Menurut Baidhowi dalam Ahmadi (1992:15), esensi pendidikan Islam tidak hanya mencakup wawasan ilmu akan tetapi juga terimplementasikan dalam pembentukan moralitas, yang penyampaiannya dilakukan secara bertahap sedikit demi sedikit untuk menuju kesempurnaan (Ibid.,14). Berdasarkan pengertian di atas Al-Bani dalam Tafsir (2001: 29) menyimpulkan bahwa pendidikan terdiri atas empat unsur, yakni: a) memelihara pertumbuhan fitrah manusia, b) mengembangkan potensi dan kelengkapan manusia yang beraneka ragam (terutama akal budi), c) mengarahkan seluruh fitrah manusia dan potensi menuju kesempurnaan, d) dilaksanakan secara bertahap.

Pendidikan Islam menurut Ahmadi (1987: 10) dirumuskan dengan segala usaha untuk mengembangkan fitrah manusia dan sumberdaya insan kamil (muttaqin) yang sesuai dengan norma Islam, yang terefleksikan dalam perilaku baik, dalam hubungannya dengan Tuhan, dengan sesama, maupun dengan alam sekitarnya. Sedangkan 
Toha (1996: 99) memberikan pengertian pendidikan Islam dengan pendidikan yang falsafah, berdasar dan tujuan serta teori-teori dibangun untuk melaksanakan praktek pendidikan didasarkan nilai-nilai dasar Islam yang terkandung dalam Al-Quran dan Hadis Nabi. definisi di atas memberikan kesimpulan bahwa pendidikan Islam, sebagai usaha-usaha yang harus dilakukan agar ghirah manusia dan sumber daya insan kamil dikembangkan sesuai norma Islam yang terkandung dalam Al-Quran, yang termanifestasikan pada praktek pendidikan yang berdasarkan nilainilai dasar Islami. Nahlawi dalam Langgulung (1981: 61) menyimpulkan empat tujuan umum bagi pendidikan Islam, yaitu; 1) Pendidikan akal dan persiapan fikiran, Allah menyuruh manusia merenungkan kejadian langit dan bumi agar dapat beriman kepada Allah, 2) Menumbuhkan potensi-potensi dan bakat-bakat asal pada kanakkanak. Islam adalah agama fitrah, sebab ajarannya tidak asing dan tabi'at asal manusia bahkan ini adalah fitrah yang manusia diciptakan sesuai dengannya, tidak ada kesukaran yang luar biasa, 3) Menaruh perhatian pada kekuatan dan potensi generasi muda dan mendidik mereka sebaikbaiknya, baik laki-laki maupun perempuan. 4) berusaha untuk menyeimbangkan segala potensi generasi muda dan mendidik mereka sebaik-baiknya, baik laki-laki maupun perempuan.

Al Abrasyi dalam Zuharini dkk (1995: 164-165) menunjukkan lima tujuan umum dalampendidikan Islam yaitu, 1) Untuk mengadakan pembentukan akhlak yang mulia, kaum muslimin dari dahulu kala sampai sekarang setuju bahwa pendidikan akhlak adalah inti pendidikan, dan bahwa mencapai akhlak yang sempurna adalah tujuan pendidikan 
yang sebenarnya. 2) Persiapan untuk mencari rizki dan pemeliharaan dari segi manfaat atau yang lebih terkenal dengan tujuan vokasional dan profesional. 3) Menumbuhkan semangat ilmiah pada pelajar dan memuaskan keingintahuan dan memungkinkania mengkaji ilmu demi ilmu itu sendiri. 4) Menyiapkan pelajar dari segi profesional, tekhnikal dan pertukangan supaya dapat menguasai profesi tertentu dan ketrampilan pekerjaan agar ia dapat mencari rizki dalam hidup disamping memelihara segi kerohanian dan keagamaan.

Islam adalah agama yang mengemban misi rahmatan lil alamin, yaitu tercapainya kerajaan dunia yang makmur, dinamis, harmonis dan lestari sehingga seluruh penghuninya merasa aman dan nyaman (Fadjar, 2003). Emosi dalam Islam telah banyak diuraiakan dalam al-Qur'an, sebagaimana emosi takut yang terurai dalam Qs. Al Qashas, 28: 21, emosi marah dalam Qs. Al-A'raf; 7: 150, emosi gembira dalam Qs. Ar Rahman, emosi benci dalam Qs. An-Nisa' 4:19, emosi cinta dalam Qs. Ali Imron 3: 14, emosi cemburu dalam Qs. Yusuf 12: 8-9, emosi sedih dalam Qs. Thaha 20:40, emosi dengki dalam Qs. Al-Baqarah 2: 109, emosi penyesalan dalam Qs. al Maidah 5:30-31, dan ayat-ayat yang menggambarkan kondisi emosi yang lainnya, yang pada prinsipnya Allah SWT telah membekali manusia dengan berbagai emosi agar mampu melangsungkan kehidupannya. Sedangkan landasan atau sumber dasar dari pendidikan Islam adalah Al-Quran dan Sunah Rasulullah (An Nahlawi, 1986:41). Kolerasi ini menyebabkan bahwa misi yang diemban kecerdasan emosional adalah bagian yang tidak terpisahkan dalam pendidikan Islam. 
Sejalan dengan misi agama Islam yang bertujuan memberikan rahmat bagi sekalian makhluk di alam ini. Maka pendidikan Islam mengidentifikasi sasarannya yang digali dari sumber ajaran Al-Quran, untuk Menyadarkan manusia secara individual pada posisi dan fungsinya di tengah makhluk lain serta tanggung jawab dalam kehdupannya, sehingga manusia mampu berperan sebagai makhluk Allah yang paling utama diantara makhluk Allah lainnya, sehingga mampu berfungsi sebagai khalifah di bumi ini, sebagaimana diuraikan dalam Qs. Shad 38 : 71-72, Allah memberikan kepada manusia suatu kedudukan yang lebih tinggi sebagaimana dalam Qs. Al Isra' 17: 70, yang bertanggung jawab terhadap dirinya dan masyarakat sebagai konsekuensi kedudukannya QS. Al Isra' 17: 15. Konsep tersebut senada dengan konsep yang ingin dibangun dalam kecerdasan emosional untuk membentuk karakter manusia dalam memahami diri sendiri dan orang lain, sehingga memiliki sikap yang relevan dengan tuntunan yang ada dalam al-Qur'an dan Hadis.

Manusia adalah mahluk homo sosios atau makhluk sosial, oleh karena itu manusia harus mengadakan interrelasi dan interkasi dengan sesamanya dalam kehidupan bermasyarakat, itulah sebabnya Islam mengajarkan tentang persamaan, persaudaraan, kegotong royongan, dan musyawarah yang dapat membentuk masyarakat itu menjadi suatu persekutuan hidup yang utuh. Prinsip hidup bermasyarakat demikian dikehendaki oleh Allah, sebagaimana yang terurai dalam Qs. Al-Anbiya 21: 92, Qs. Ali Imran 3: 103, QS. Al Hujurat 49 : 10 dan QS. Ar Rum 30: 22. Menyandarkan manusia terhadap pencipta alam dan mendorongnya 
untuk beribadah kepada-Nya. Selain itu manusia juga disebut sebagai mahluk religius atau makhluk berketuhanan, sikap dan watak religiusitasnya perlu dikembangkan sedemikian rupa sehingga mampu menjiwai dan mewarnai kehidupannya, sebagai bentuk kemampuan untuk beragama dan kemampuan itu berada dalam fitrahnya secara alami, sebagaimana terurai dalam Qs. Al An‘am 6: 102-103.

Dengan kesadaran demikian, maka manusia sebagai khalifah diatas bumi dan yang terbaik diantara makhluk lain, akan mendorong untuk melakukan pengelolaan, mengeksploitasikan serta memberdayagunakan ciptaan Allah untuk kesejahteraan hidup bersamasama dengan lainnya. Pada akhirnya, kesejahteraan yang diperolehnya itu digunakan sebagai sarana untuk mencapai kebahagiaan hidup di akhirat. Bukankah dunia ini bagaikan ladang untuk digarap dan ditanami dengan tanaman yang buahnya berguna bagi hidupnya di akhirat nanti (M. Arifin, 1991:33-37). Sasaran pendidikan Islam dan kecerdasan emosional menurut An-Nahlawi (1995: 116) adalah berusaha membentuk perilaku manusia perilaku kesadaran, baik dalam perilaku individu maupun sosial sehingga hidupnya mempunyai "makna" dalam hidup dan kehidupan ini secara luas.

Kecerdasan emosional berperan dalam membesarkan dan mendidik peserta didik, hingga penyandaran akan arti penting konsep ini baik di lapangan kerja maupun diseluruh sektor kehidupan baik dalam keluarga, sekolah maupun kehidupan bermasyarakat yang menuntun manusia untuk saling berhubungan. tentunya pendidikan Islam disini mempunyai kepentingan secara kolektif bagaimana mengupayakan agar 
manusia dapat mewujudkan penanaman nilai-nilai ketaqwaan dan akhlak serta menegakkan kebenaran dalam rangka membentuk manusia yang berbudi luhur menuju ajaran Islam. Konsep kecerdasan emosional ini yang turut akan membicarakan akan arti penting penguasaan diri dan bagaimana sikap dan reaksi dalam berinteraksi dengan lingkungannya sesuai dengan tujuan pendidikan Islam yang mengupayakan perwujudan manusia yang kaffah.

\section{Implikasi Konsep Kecerdasan Emosional dalam Pendidikan Islam}

Implikasi yang ditimbulkan dari kecerdasan emosional dalam pendidikan Islam untuk mempengaruhi penyesuaian pribadi dengan sosial seseorang, dengan bentukk tuntutan adanya kemampuan penyesuaian diri peserta didik agar menjadi lebih dewasa dalam menyikapi perkembangan dirinya dan lingkungan yang dimilikinya. Hal tersebut bisa berubah manakala mampu memanage emosi yang berada pada dirinya setidak-tidaknya mampu mengarahkan emosi sebagai motivasi bagi kehidupan sehari-hari, menambah rasa nikmat bagi pengalaman sehari-hari. Untuk itu tantangan dalam pendidikan Islam justru akan semakin kompleks dan menantang, hal tersebut terlihat dari perubahan-perubahan dan pergeseran pola hidup yang semula bercorak sosial religius kepada pola individual materialistis dan sekuler.

Dalam masyarakat modern khususnya, telah terjadi perubahanperubahan bahkan sampai pada cara orang tua yang banyak memberikan kelonggaran dan "serba boleh" kepada anak remaja, sehingga tidak menutup kemungkinan bebrapa pelanggaran terhadap ajaran-ajaran 
agama tidak mendapat reaksi keras dari orang tua sebagai penanggung jawab anak atau remaja secara menyeluruh. Reaksi-reaksi yang dihasilkan dari interaksi diri dengan lingkungan sosialnya, emosi tentu akan menyiapkan tubuh melakukan tindakan-tindakan yang sekiranya dapat dijadikan sebagai penyesuaian dirinya. Kalau sekiranya emosi seseorang dalam kondisi yang tidak stabil, tidak menutup kemungkinan dari ketegangan emosi akan mengganggu keterampilan motorik dan aktivitas mental serta suasana psikologis seseorang dan hal ini jelas akan mengganggu hasil dari interaksi sosialnya.

Kecerdasan emosional memberi dampak yang tidak sedikit pada dunia pendidikan terutama dalam konteks pendidikan Islam. Pendidikan Islam memiliki tujuan pokok untuk membentuk manusia yang bertaqwa kepada Allah SWT, dimana penekanannya adalah pada agama Islam itu sendiri jelas, bahwa keterlibatan kajian agama sangat mungkin terkait dengan kajian kecerdasan emosional. Bahkan, pendidikan Islam memperhatikan penataan individual dan sosial yang diharapkan dapat membawa manusia pada pengaplikasian Islam secara komprehensif. Seseorang muslim dituntut untuk dapat menguasai emosinya (cerdas dalam emosi) karena emosi merupakan suatu bentuk komunikasi yang merupakan sumber penilaian diri dan sosial. Bagi pandangan seseorang lebih-lebih pada seorang anak akan dapat mewarnai corak kehidupannya. Rekasi emosional apabila diulang-ulang akan menjadi kebiasaan seseorang, dan keberhasilan pendidikan Islam dilihat dari hasil dari reaksi dan perkembangan emosi anak didik, agar terarah pada hal yang positif dan lebih mengarah pada tujaun pendidikan Islam itu sendiri, 
maka akan memberikan kontribusi pada tingkat keberhasilan pendidikan Islam.

Reaksi-reaksi dan perubahan-perubahan yang ditumbulkan dari hasil pergesekan emosional tidak dapat dipisahkan antara hubungan emosi yang satu dengan lainnya, hal ini sangatlah berkaitan sebagaimana rangkaian mata rantai yang satu dengan yang lainnya saling berkaitan dan saling mendukung. Pendidikan Islam tentunya juga harus mendapat perhatian agar keberhasilan dalam pendidikan Islam dapat tercapai. Maka, disini penulis berusaha mengkaitkan dengan fungsi dan peran konsep kecerdasan emosional dalam pendidikan Islam, sehingga harapan untuk mempertemukan dan "mengawinkan" kecerdasan emosional yang banyak ditawarkan oleh para psikolog barat dengankonsep pendidikan Islam dapat tercapai.

\section{Ukuran Keberhasilan Kecerdasan Emosional dalam Pendidikan Islam}

Upaya untuk mengetahui akan keberhasilan, kecerdasan emosional dalam pendidikan Islam, maka penulis menggunakan beberapa perspektif pendekatan, yaitu: dasar, obyek, dan tujuan pendidikan Islam. Sehubungan dengan perspektif pendidikan Islam pada kecerdasan emosional adalah sebagai berikut:

\section{Kecerdasan Emosional dalam Perspektif Dasar Pendidikan Islam}

Sebagaimana yang telah dikemukakan didepan bahwa setiap usaha, tindakan, atau kegiatan untuk mencapai tujuan tertentu harus mempunyai landasan yang melandasi seluruh peran kecerdasan 
emosional khusunya dalam pendidikan Islam, baik dalam penyusunan teori, perumusan tujuan, cita-cita dan pelaksanaannya. Penulis mencoba untuk mengkritisi kembali konsep kecerdasan emosional yang telah ditawarkan oleh beberapa pengkaji dari psikolog-psikolog barat, ternyata masih terlihat sedikit adanya kebersinggungan danbahkan adanya keterlepasan bahasan antara konsep kecerdasan emosional dengan kajian agama terutama kalau dikaitkan dengan pendidikan Islam

Kajian-kajian yang ditawarkan dalam kecerdasan emosional lebih cenderung membahas mengenai bagaimana kesadaran diri ditekankan, sehingga nantinya dapat mengetahui apa yan gdirasakan pada suatu saat, dan menggunakannya untuk memandu pengambilan keputusan diri sendiri, memiliki tolok ukur yang realistis atas kemampuan diri dan kepercayaan diri. Lebih lanjut, melangkah kepada pengaturandiri agar dapat menangani emosi sedemikian rupa sehingga berdampak positif kepada pelaksanaan tugas, peka terhadap kata hati dan sanggup menunda kenikmatan sebelum tercapainya suatu sasaran, mampu pulih kembali dari tekanan emosi. Dari adanya kesadaran diri dan pengaturan diri ini akan menumbuhkan motivasi sehingga dapat menggunakan hasrat yang paling dalam untukmenggerakkan dan menuntun diri menuju sasaran, membant mengambil inisiatif dan bertindak sangat efektif, dan untuk bertahan menghadapi kegagalan dan frustasi.

Mulai pembahasan tentang kesadaran diri dan bagaimana dapat mengatur diri sendiri serta tumbuhnya rasa motivasi dalam diri, jarang sekali dikaji dan dikaitkan dengan fungsi dan peran agama. Biar bagaimanapun juga untuk keterkaitan bahan kajian emosi tetap tidak 
luput menggunakan landasan dan pijakan konsep-konsep agama yang elemen-elemennya telah banyak dibahas sebagai suatu pijakan dan landasan. Lebih-lebih kalau keterkaitannya dengan pendidikan Islam. Pembahasan mengenai kecerdasan emosional dari intrapribadi diatas penulis mencoba untuk menganalisis dari sisi antarpribadi dalam lingkup kecerdasan emosional. Empati yang merupakan langkah awal untuk dapat memahami emosi orang lain agar dapat merasakan yang dirasakan orang lain,mampu memahami perspektif mereka, menumbuhkan hubungan saling percaya dan menyelaraskan diri dengan bermacam-macam orang. Pada kajian selanjutnya, yaitu ketrampilan sosial: yang menangani emosi dengan baik ketika berhubungan dengan orang lain dan dengan cermat membaca situasi dan jaringan sosial; berinteraksi dengan lancar; menggunakan ketrampilan-ketrampilan ini untukmempengaruhi dan memimpin, bermusyawarah dan menyelesaikan perselisihan, dan untuk bekerja sama dan bekerja dengan tim.

Terlihat dari konsep kecerdasan emosional dalam kajian antar pribadi yang meliputi empati dan kerampilan sosial diatas, ada kajian yang mungkin sengaja untuk tidak disinggungkan mengenai hubungan manusia dengan ajaran Tuhannya. Hubungan antar pribadi yang lebih menekankan pada adanya sikap empati dan ketrampilan sosial, terlihat lebih menekankan bagaiman hubungan secara horizontal (sesama) antar manusia. Kalau dalam kajian Islamnya, lebih menekankan pada Hablum Minannas daripada menyentuh Hablum Minalah-Nya. Untuk gambaran kasarnya, dapat diambil benang merahnyah bahwa konsep kecerdasan emosional yang ditawarkan oleh para psikolog barat lebih cenderung 
meyajikan konsep kecerdasanemosional antara diri dansosialnya, tidak mencoba untuk dikaitkan elemen-elemen ajaran Tuhannya.

Pergerakan emosional seperti yang telah diuraikan pada bab sebelumnya tentunya akan menimbulkan reaksi dan perubahan yang berakses pada sosial budaya, maka pendidikan agama hendaknya tetap diutamakan. Sebab pendidikan agama memiliki muatan nilai-nilai moral, etika, dan pedoan hidup sehat yang universal (termasuk kesehatan emosional) dan abadi sifatnya.

\section{Kecerdasan Emosional dalam Perspektif Obyek Pendidikan Islam}

Manusia sebagai khalifah di atas bumi dan terbaik diantara makhluk Allah yang lain, terdorong untuk melakukan pengelolaan, mengeksploitasi serta memberdayakan ciptaan Allah untuk kesejahteraan hidup bersama-sama dengan yang lainya. Tentunyah, pada akhirnya kesejahteraan yang diperolehnya itu digunakan sebagai sarana untuk mencapai kebahagiaan hidup di akhirat, mengingat dari apa yang diusahakan untuk kepentingan bersama-sama, maka harapan yang muncul adalah munculnya usaha untuk berperilaku atas dasar kesadaran, baik bagi diri sendiri, masyarakat, lingkungan dan kepada sang pencipta, sehingga hidupnya mempunyai makna dalam kehidupan secaraluas.

Kesadaran emosional yang turut menekankan pada kesadaran akan keberadaan diri serta hidup berperilaku dalam lingkungannya, hal ini sangat sepadan dengan sasaran pendidikan zislam yang teridentifikasi dari sumber ajaran Al-Quran. Sebagaimana upaya terhadap penyadara manusia secara individu pada posisi danfungsinya terhadap makhluk lain, serta tanggung jawab dalam hidupnya. Sisi yang kurang dibahas dari 
konsep kecerdasan emosional yang banyak ditawarkan oleh psikolog barat apabila dilihat dalam kacamata pendidikan Islam, adalah penekanan yang terfokus pada dimensi horizontal kehidupan manusia. Sehingga penanganan diri pada aspek kesadaran fungsi manusia terhadap pencipta alam dan mendorong untuk beribadah kepada-Nya kurang dan bahkan tidak dibahas dan dikaitkan. Bagaimanapun juga bahwa konsep kecerdasan emosional apabila dilihat dari obyek pendidikan Islam tetaplah sangat mendukung konsep pendidikan Islam pada tataran pendekatan-pendekatan yang mengarah pada tugas dan tanggung jawab manusia sebagai khalifah di bumi.

\section{Kecerdasan Emosional Dalam Perspektif Tujuan Pendidikan Islam}

Bila konsep kecerdasan emosional dikaitkan dengan proses sebagaimana yang dilakukan oleh pendidikan Islam, maka konsep kecerdasan emosional sebenarnya turut membentuk kepribadian manusia sebagaimana yang dilakukan juga oleh pendidikan Islam meskipun pangkalnya mengalami perbedaan, dimana konsep kecerdasan emosional berhenti pada tataran penerapan penangangan emosional dalam diiri dan pengelolaannya serta meanfaatkannya dalam hubungan bersosialnya sehingga terwujudnya kedewasaan emosional dalam berperilaku di lingkungannya, sedangkan pendidikan Islam akan berakhir pada penanaman nilai ketaqwaan dan akhlaak serta menegakkan kebenaran dalam rangka membentuk manusia yang berpribadi dan berbudi luhur.

Konsep kecerdasan emosioanl dankonsep pendidikan Islam memang selama ini memiliki garis yang bersinggungan dan saling menunjang antar konsep yang satu dengan yang lainnya. Sumbangan 
pemikiran para psikolog barat atas tercetsunya konsep kecerdasan emosional lebih banyak mendukung terhadap jalannya proses pendidikan Islam, meskipun tidak bisa dipungkiri juga bahwa konsep kecerdasan emosional memiliki beberapa kekurangan terhadap beberapa hal yang berkaitan dengan pengembangan dan peningkatan nilai ketaqwaan terhadap Tuhannya. Jadi jelas, pendekatan kajian emosi yang diramu dalam konsep ajaran Islam turut menopang keberhasilan dalam pendidikan Islam. Sebagaimana ajaran Islam tentang orang tua yang mempunyai tanggung jawab besar terhadap tumbuh kembang anak agar nantinya dapat berilmu dan beriman.

\section{Kesimpulan}

Dari uraian tentang kecerdasan emosional dalam perspektif pendidikan Islam dalam pembahasan terdahulu, dapatlah diambil kesimpulan bahwa konsep kecerdasan emosional dalam pendidikan emosional yang ditawarkan oleh para psikolog yang tidak disentuhkan dan dipadukan dengan konsep-konsep agama yang sebenarnya saling memperkuat. Manusia dengan berbagi emosi yang mampu membuat kelangsungan hidup manusia. Bekal emosi ini menuntu manusia untuk dapat mengemban dalam kehidipan diri dan sosial sebagai penialaian keberhasilan sesuai dengan rangkaian usaha membimbing, mengarahkan potensi hidup manusia yang berupa kemampuan-keampuan dasar dan kemampuan belajar, sehingga terhadilah perubahan di dalam kehidupan pribadi sebagai makhluk individu dan sosial (QS. Al Hujarat, 49:13). 
Kecerdasan emosional memang merupakan istilah yang tergolong relatif harus akan tetapi kalau dikaji lebih dalam lagi sebenarnya isi dan kajiannya tidaklah tergolong baru. Bukankah dalam ajaran Islam sendiri yang termasuk pengembangannya dalam pendidikan Islam ada tentang kesadaran diri (QS. Az Zumara: 15), kontrol diri (QS. Al Hadid: 23), ketekunan, semangat, motivasi dalam diri (QS. Thaaha: 67-68), sikap empati terhadap orang lain (QS. An Nur: 2), dan kecakapan sosial (QS. Al Hujurat: 13). Presosi ini pada intinya memang akan bermuara kepada bagaimana seseorang mengenal. Menguasai dan mengendalikan emosi yang semuanya itu sering disebut dengan sikap kedewasaan seserorang atau istilah populernya adalah kecerdasan emosional.

Keterkaitan konsep kecerdasan emosional dengan konsep pendidikan Islam selama ini terlihat jelas pada tingkatan hubungan diri (pengendalian diri) dan hubungan sosial antar manusia (horizontal). Tetapi tidak dipungkiri juga bahwa konsep kecerdasan emosional memiliki beberapa kekurangn terhadap beberapa hal yang berkaitan dengan pengembangan dan peningkatan nilai ketaqwaan terhadap Tuhan Yang Maha Esa.

\section{Daftar Pustaka}

Abrasyi, Al Athiyah.1993. Dasar-Dasar Pokok Pendidikan Islam. PT Bulan Bintang Jakarta.

Ahmadi. 1987. Ilmu Pendidikan Islam. Salatiga: Fakultas IAIN Wali Songo.

Al Quran dan Terjemahannya. Semarang: Toha Putra.

Arifin, M. 1991. Ilmu Pendidikan Islam Suatu Tinjauan Teoritis dan Praktis Berdasarkan Pendekatan Interdisipliner. Jakarta: Bumi Aksara. 
Cooper, Robert K. dan Ayman Sawaf. 2002. Kecerdasan Emosional dalam Kepemimpinan dan Organisasi. Jakarta: Gramedia Pustaka Utama.

Darodjat, Zakiah. tt. Problem Remaja di Indonesia. Jakarta: Bulan Bintang.

Goleman, Daniel. 2003. Emotional Intellegence. Jakarta: Gramedia Pustaka Utama.

Khaidi, Ilham. 2004. Hubungan Kecerdasan Emosional dengan Religiusitas Siswa, Skripsi. STAIN Salatiga.

Langgulung, Hasan. 1987. Manusia dan Pendidikan. Jakarta: PT. Al Husna Zikra.

Marimba, Ahmad D. 1994. Menuju Kesempurnaan Akhlak. Bandung: Mizan.

Music, Graham. 2003. Emosi Filsafat Pendidikan Islam. Edisi revisi. Jakarta: Bumi Aksara.

Muzayyin, Arifin. 2003. Filsafat Pendidikan Islam. Jakarta: Bumi Aksara.

Nahlawi, Abdurrahman. 1995. Pendidikan Islam di Rumah Sekolah dan Masyarakat. Jakarta: Gema Insani Pers.

Nata, Abudin. 1997. Filsafat Pendidikan Islam 1. Jakarta: Logos Wacana Ilmu.

Sten, Steven J. dan Howard E. Book. 2004. Ledakan EQ 15 Prinsip Dasar Kecerdasan Emosional Meraih Sukses. Bandung: Kaifa.

Tafsir, Ahmad. 1992. Ilmu Pendidikan dalam Perspektif Pendidikan Islam. Bandung: PT Remaja Rodsakarya.

Toha, Chabib. 1992. Kapita Selekta Pendidikan Islam. Jakarta: Pustaka Pelajar.

Zuhairini, dkk. 1995. Filsafat Pendidikan Islam. Jakarta: Bumi Aksara. 